\title{
Eesti õpilaste haavatavuse aspekte 6. klassi õpilaste fookusgruppide põhjal ${ }^{1}$
}

\author{
Andrus Tins \\ Tartu Ülikooli ühiskonnateaduste instituudi \\ sotsioloogia magistrant \\ andrus.tins@ut.ee
}

\begin{abstract}
Teesid: Käesolevas artiklis uuritakse Eesti laste haavatavuse aspekte nende enda perspektiivist lähtuvalt. Empiirilise andmestikuna on kasutatud autori poolt 2018. ja 2019. aastal läbi viidud fookusgruppide andmeid. Artikkel annab ülevaate olulisematest tulemustest ja paigutab need haavatavust puudutavate lapsepõlveuuringute laiemasse konteksti. Näiteks osutatakse artiklis, et uuringu põhjal vähendab laste haavatavust oluliselt turvaline suhe perekonna ja teiste lähedastega. Materiaalsed väärtused on haavatavust vähendava tegurina lastele olulised, kuid ei domineeri võrreldes turvalise kodu, heade inimsuhete ja eneseteostusvõimalustega (sport ja muud huvialad). Muret tekitavana tõid lapsed välja palju kohustusi, veebiturvalisuse, globaalsed keskkonnaprobleemid ning rahvusvahelised konfliktid, hierarhilised suhted õpetajatega, meedia vahendatud negatiivsed sõnumid.
\end{abstract}

Märksõnad: ebaturvalisus, heaolu, laste haavatavus, temaatiline analüüs, turvalisus

\section{Sissejuhatus}

Laste heaolu kui uurimisvaldkond on viimastel aastakümnetel rahvusvahelisel tasandil teinud läbi märkimisväärse arengu (Dinisman \& Ben-Arieh 2015; Hunner-Kreisel \& Kuhn 2010; Minkkinen 2013; Camfield \& Skevington 2008). Alates 2009. aastast on laste heaoluindikaatorite rahvusvaheline võrgustik (ISCI) ankeetküsitlusena (arvandmed) viinud kolmes laines läbi Children's Worlds (ISCWeB.org) rahvusvahelist laste heaolu uuringut. Kahes viimases laines on osalenud ka Eesti. Kvantitatiivse uurimissuuna kõrval on arenemas ISCI võrgustiku kvalitatiivne suund (Children's Understandings of WellBeing - CUWB), mille raames lastega tehtavate kognitiivsete intervjuude ja ülesannetega selgitatakse nende arusaamu heaolu ja haavatavusega seotud teemade kohta (Kutsar \& Soo \& Raid 2018). 
Käesolevat teemat ajendasid uurima uuringu Children's World varasemad tulemused, millest selgus, et 6. klassi õpilaste eluga rahulolu hinnangud on oluliselt madalamad kui 4. klassi õpilaste ja 2. klassi õpilaste õnnelikkuse hinnangud. 8aastaste (2. klass) eluga rahulolu hinnangutes on maksimumhinnanguid andnud $76 \%$ lastest. 10aastastest (4. klass) on kõrgeima hinnangu eluga rahulolule andnud $68 \%$ ja 12 aastastest (6. klass) pooled vastanutest (Kutsar et al. 2018). Teadaolevalt ei ole eksploratiivsel kvalitatiivsel meetodil (vt lähemalt Given 2008: 327) laste haavatavust suurendavaid / heaolu vähendavaid aspekte Eesti õpilaste hulgas kuigi palju uuritud, seekaudu võiks käesoleva uuringu kvalitatiivsel materjalil põhinevad tulemused olla oluliseks panuseks nimetatud temaatika paremal mõistmisel. Muuhulgas on uurimus ka panus Children's World uurimisvõrgustiku kvalitatiivse haru (CUWB) töösse.

Et laste seisukohad ja tõlgendused on seotud konkreetse ühiskonnaga ning on aja ja ruumispetsiifilised, siis on arvandmete analüüsi kõrval oluline kvalitatiivne uurimisviis. Varem on näiteks eesti laste loodud heaolu kujutavatelt joonistustelt selgunud, et neile on elus tähtsaimad pereliikmed, sõbrad ja lemmikloomad ning olulisim heaolu loov keskkond laste elus on kodu (Kutsar et al. 2018). Laste haavatavust põhjustavaid tegureid (heaolu vähendavaid faktoreid) on Eesti seni vähe uuritud. Järgnevas esitatakse haavatavuse ja subjektiivse heaolu määratlus ja käsitlus (nii nagu seda mõistetakse käesoleva uurimuse raames) ning lapsepõlve kaasaegne sotsioloogilise käsitluse raamistik.

\section{Haavatavus ja subjektiivne heaolu: terminoloogilisi ja uurimuslikke lähtekohti}

Käesolevas artiklis on haavatavust ja subjektiivset heaolu (SH) käsitletud kui omavahel tihedalt seotud mõistete paari. Haavatavust põhjustavad aspektid, mil on nii objektiivne kui ka subjektiivne komponent, mõjutavad suuremal või vähemal määral lapse heaolu ning vice versa, omades nii objektiivset kui subjektiivset komponenti.

Heaolu kui sotsiaalse nähtuse puhul on eristatud objektiivset ja subjektiivset heaolu. Objektiivne lähenemisviis defineerib heaolu elukvaliteedi indikaatorite (sissetulek, eluase, toit jms) ning inimese sotsiaalsete omaduste (haridus, tervis, poliitiline osalus, sotsiaalsed võrgustikud, sidemed) kaudu (Diener \& Suh 1997). SH on määratletud kui kategooriat, mille puhul inimesed annavad enda elule üldhinnangu seoses oma elus toimuvate sündmustega, oma keha ja meele seisundiga, samal ajal arvesse võttes üldisi asjaolusid, mis nende elu mõjutavad (Diener 2006: 400). 
SH kui analüütilise kategooria kõrval tõstatub küsimus, millised on need tegurid, mis mõjutavad ja kujundavad, tõstavad või langetavad SH hinnangut. Laste SH puhul on Sabine Andresen (2014) esitanud lapsepõlvesotsioloogilise lähenemise, kus ta defineerib lapsepõlve kui iseäranis haavatavat elukaare perioodi ja lapsed on käsitletavad kui sotsiaalne riskirühm. Samas ei tohi lapsi vaadelda ka kui ohvreid puhtalt nende lapseks olemise tõttu. Haavatavuse määratlemisel lähtub käesolev uurimus Andreseni (2014) loodud lapsepõlvesotsioloogilisest baasraamistikust. Selle raamistiku järgi põhjustavad haavatavust need laste elu aspektid, mis seavad ohtu laste heaolu lühemas või pikemas kronoloogilises perspektiivis. Andreseni järgi on lapsed sotsiaalne rühm, kelle puhul on ideaaliks arengu- ja haridusvõimaluste loomine, kaitse ja õiguste tagamine hea käekäigu huvides. Lapse heaolu varastel eluperioodidel mõjutab tema elukvaliteeti ka tulevikus (riskinooreks või mittestandardseks täiskasvanuks kujunemise minimeerimise kaudu jms) - juba seetõttu on oluline olla teadlik laste haavatavust põhjustavatest eluaspektidest. Ebaturvaliste eluaspektide mõjud väljenduvad laste haavatavust suurendavate ning SH-d vähendavate mõjudena. Käesolev uurimus käsitleb laste $\mathrm{SH}$ ja haavatavust kui ühe süsteemse terviku osasid, mille puhul laste kui sotsiaalse rühma haavatavust vaadeldakse ebaturvalisuse markerite kaudu - lapse eakohast arengut mittesoosivate protsesside, ebaturvaliste olukordade, suhete, elukeskkondade põhjal - ning laste kogetavat haavatavust ja riskifaktoreid SH-d mõjutavana (vrd Andresen 2014). Turvalise keskkonna kui SH põhitingimuse on Suurbritannia andmetele tuginedes välja toonud Gwyther Rees ja Jenny Lee (2005). Laste arenguvõimaluste, hariduse ja osaluse kõrval esitab ka ÜRO lapse õiguste konventsioon olulise valdkonnana lastekaitse (Lapse õiguste konventsioon, 1991), millega väljendatakse laste ohustatumat positsiooni võrreldes täiskasvanutega.

Erinevad autorid on haavatavust käsitlenud mitmeti. Robert E. Goodin (1985) on haavatavust määratlenud peamiselt sõltuvuslikust suhestumisest lähtuva nähtusena. Olles teiste inimeste poolt potentsiaalselt haavatav, sõltub laps nende tegudest ja tegematajätmistest juhul, kui ta vajab nende abi (Goodin 1985: 110). Laste puhul on lisaks põhivajadustele olulised ka füüsilist, intellektuaalset ja emotsionaalset arengut toetav keskkond ning kuna lapsed sõltuvad olulisel määral lähedastest isikutest, kes selle keskkonna kujundavad, on lapsed iseäranis haavatavad, kui neid ümbritsev keskkond on ebasoodus või takistab arengut (Mullin 2014). Käesolevas uurimuses on haavatavusena käsitletud laste $\mathrm{SH}-\mathrm{d}$ vähendavaid tegureid, mis on lapsele potentsiaalsed riskid ja ohud.

Millisena täpsemalt haavatavust kujundavaid võimalikke ohte ja riske tajutakse, sõltub konkreetsest diskursusest ehk lapsepõlveriskide käsitlusviisist. Kui seadusandluse ja sotsiaalsete praktikate näol on välja kujunenud üldised - 
eelkõige täiskasvanute sõnastatud - ühiskondlikud hoiakud ja arusaamad laste sotsiaalsele keskkonnale esitatavatele nõuetele, siis laste enesekohaste hinnangute kaudu saab avada lisamõõtme ning õppida tundma laste perspektiivi iseenda haavatavusele. Lähtuvalt eesmärgist tuua eelkõige välja just laste endi vaatenurk, on siinkohal valitud andmekogumise meetodiks fookusgrupiintervjuu. Oleks ju ka raske rääkida laste õigustest ja vajadustest nende endi häält kuuldavaks tegemata.

\section{Sotsioloogiline lapsepõlvekäsitlus: lapsepõlv elukaare osana}

Jens Qvortrup (2009) on rõhutanud, et lapsepõlv esineb mingil kujul kõigis ühiskondades ja see viitab asjaolule, et lapsepõlv baseerub algselt mitte-sotsiaalsel ainesel. Lapsepõlve käsitlemine täiskasvanute poolt, laste roll ning õigused on ajas palju muutunud. Viimastel aastakümnetel on olulise lapsepõlvekäsitlust uuendava mõjuga olnud ÜRO lapse õiguste konventsioon (Lapse õiguste konventsioon 1991), millega on liitunud ka Eesti. Lapsepõlve mõjutavad seega suuresti konkreetne aeg ja ühiskond.

Alates 1980. aastate lõpust on hakatud lapsepõlve käsitlema indiviidi selgelt eraldiseisva eluperioodina, mille puhul lapsi nähakse aktiivsete sotsiaalsete agentidena ehk toimijatena, kelle puhul pole oluline ainuüksi lõppresultaat ehk saamine täiskasvanuks, vaid ka nende heaolu enne seda, sest lapsepõlvekogemustel ja läbielamistel lapseeas on otsene mõju lapse SH-le, aga ka lapse tulevikuperspektiividele (Qvortrup 1991). Laste kasvuea heaolu tase kujundab kaudselt ühiskonda tulevikus (Kutsar et al. 2018). Tobia Fattore, Susann Fegter ja Christine Hunner-Kreisel on rõhutanud, et laste heaolu ei ole staatiline ja kontekstivaba; laste arusaamu ja kogemusi tuleb vaadelda kindla aja ja ruumi kontekstis ehk sotsiaalse konstruktsioonina (Fattore et al. 2019).

Empiirilised uuringud on näidanud, et heaolu ja haavatavuse puhul on keskseks mõjuteguriks turvalisus või selle puudumine (Andresen 2014; Kutsar et al. 2018). Ebaturvalised olukorrad, suhted, ümbritsevad keskkonnad on laste haavatavust ennustavad faktorid. Senised uuringud on näidanud, et ühiskonna vaesuse/rikkuse objektiivsed näitajad (nt Gini indeks) ei määra statistiliselt oluliselt laste subjektiivset eluga rahulolu (Kutsar et al. 2018; Lee \& Yoo 2015). Varasemad uuringud on samuti esile toonud, et lapsele on suurima ja olulisima mõjuga teda ümbritsevad inimesed, olulised teised: vanemad, sõbrad, õpetajad (Cobb 1976; Lee \& Yoo 2015). Head ja harmoonilised suhted lapsele oluliste lähedaste isikutega (eestikeelsetes uurimustes on neid vahel nimetatud ka inglisekeelsest väljendist significant others tuletatud vastega "olulised teised") 
kujundavad suure osa subjektiivsest heaolust. Vaesuse suhtes on lastega pered/ lapsed üks haavatavamaid sotsiaalseid gruppe (Kutsar et al. 2018), kuid vaesuse kogemise subjektiivne tunnetus erineb isikuti ja sõltub suhetest lähedastega.

Heaolu subjektiivse mõõtme juures toob Asher Ben-Arieh (2006) aluspõhimõtetena lisaks uuele lapse agentsust rõhutavale lapsepõlvekäsitlusele välja: (1) bioökoloogilised käsitlusviisid, mis näevad lapse arengut ja heaolu dünaamilise protsessina lapse ja teda ümbritseva keskkonna vahel (Bronfenbrenneri bioökoloogiline arengu mudel (Bronfenbrenner \& Morris 1998)), (2) lapse perspektiivi arvestamise ehk subjektiivse hinnangu arvessevõtmise.

Sabine Andresen (2014) toob haavatavuse/heaolu dimensioonidena esile süsteemse, struktuurse ja individuaalse mõõtme. Tuginedes Urie Bronfenbrenneri bioökoloogilisele mudelile saab esitada süsteemsed faktorid, mille kohaselt kujundavad laste elu neli suurt sfääri. Iga sfäär võib lapse elu turvalisuse/ ebaturvalisuse skaalal vastavalt mõjutada. Nendeks sfäärideks on protsessid, isikud, kontekst ja aeg. Last ümbritsevas miljöös on tooniandvana eristatavad mitu eritasandilist sotsiaalsete mõjude süsteemi (mis moodustavad kokku lapse sotsiaalse maailma): mikro-, meso-, ekso-, makro- ja kronosüsteem (Bronfenbrenner 1994). Mikrosüsteem moodustub lapse kõige lähemast ümbrusest (kodu, lähiümbrus, indiviidid, kellega laps kokku puutub, tegevused ja rollid, mida laps ja tema lähedased täidavad ning see, kuidas need tegevused on sotsiaalselt interpreteeritud). Mesosüsteem koosneb mikrosüsteemide omavahelistest suhetest (formaalsete ja mitteformaalsete sotsiaalsete võrgustike ning institutsioonide interaktsioonist, millel on kindlad ülesanded ja reeglid (kodu, perekond vs tervishoiu- ja haridussüsteem, sotsiaalteenused jms)). Eksosüsteemi mõjud avalduvad lapsele vahendatult, laps ei ole selle süsteemi osaga ise otseses kokkupuutes (nt vanema töökaotus mõjutab last, kuid laps otseselt tööturuga seotud pole). Makrosüsteemid on ideoloogilised raamistikud (kultuur, subkultuur, seadusandlus, seadusandlik praktika jms). Kronosüsteem väljendub lapse elukaarel kogetud isiklike (nt sündmused perekonnas (vanemate lahutus jms) ja ühiskondlike (nt laste õiguste olukorra muutus ühiskondlikus praktikas) sündmuste kaudu.

Ühena struktuursetest mõjuritest võib välja tuua vaesuse, millel võib olla oluline mõju subjektiivsele heaolule. Lapse ja teda ümbritseva keskkonna interaktsiooni saab vaadelda struktuurse dimensioonina, mis kajastab konkreetses ajas ja ruumis käibivaid sotsiaalseid praktikaid. Samas tuleb arvesse võtta, et haavatavaid lapsi ei tohi stigmatiseerida, pidades neid automaatselt riskilasteks või ohvriteks, kuna haavatav laps võib olla samaaegselt ka tugev laps (Andresen 2014). Viimane on seotud individuaalse haavatavuse dimensiooniga, mille kohaselt oleneb konkreetse isiku haavatavus/heaolu ka puhtalt personaalsetest aspektidest (indiviidi psühholoogiline profiil, uskumussüsteem, 
bioloogilised, füsioloogilised eripärad jms). Varasemad uuringud on esile toonud asjaolu, et lapsele on suurima ja olulisima mõjuga teda ümbritsevad inimesed, olulised teised: vanemad, sõbrad, õpetajad (Cobb 1976; Lee \& Yoo 2015). Head ja harmoonilised suhted oluliste teistega kujundavad suure osa subjektiivsest heaolust (haavatavust minimeerivad aspektid).

Kirjeldatud bioökoloogiline mudel (Bronfenbrenner 1994) aitab mõista lapse kui indiviidi sotsiaalse keskkonna ja interaktsiooni olemust ning keerukust lapsepõlvesotsioloogilise raamistikuna. Järgnevalt on esitatud selles raamistikus käsitletavad laste tajutud haavatavuse aspektid tüpoloogilise mudelina. Nimetatud mudel (Fattore et al. 2007) on võetud ka aluseks käesoleva uurimuse raames tehtud fookusgruppide analüüsil, et laste haavatavuse mõjuaspekte vastavalt grupeerida ja süstematiseerida.

\section{Laste elusfäärid: tüpoloogiline mudel}

Käesoleva uurimuse raames tehtud fookusgruppide analüüsi puhul on lähtutud Tobia Fattore, Jan Masoni ja Elizabeth Watsoni (2007) kvalitatiivsete meetoditega teostatud uuringute käigus välja töötatud lapse haavatavust/heaolu käsitlevast elusfääride mudelist. Mudeli väljatöötamisel tuginesid uurijad laste endi selgitustele ja nägemustele oma elu erinevatest tahkudest. Selle mudeli järgi koosneb lapse elu viiest suurest sfäärist, mille olukord avaldab vastavalt mõju lapse haavatavusele/SH-le: (1) autonoomia ja agentsus, (2) kaitstus ja turvatunne, (3) lapse mina, (4) materiaalsed ressursid, (5) füüsiline keskkond ja kodu. Järgnevalt on toodud eelnimetatud viie sfääri/domeeni kirjeldused ning Fattore, Masoni ja Watsoni (2007) kvalitatiivse uurimuse tulemused.

1. Autonoomia ja agentsus. See sfäär on seotud vabalt tegutsemise ja valikute tegemisega. See ei tähenda tingimata sõltumatust, kuid väljendab eeldust, et laps on teatud viisil autonoomne. Agentsuse all mõeldakse tegutsemist oma vajadustest lähtuvalt, ennast puudutavate moraalsete otsuste tegemist. Haavavad on protsessid, mis ei võimalda autonoomiat ja eakohast agentsust või selle arengut.

Fattore, Mason ja Watson (2007) leidsid, et lastele on nende heaolu tagamisel/ haavatavuse minimeerimisel olulised autonoomiat võimaldavad sotsiaalsed suhted, turvalised suhted täiskasvanutega; lapsele sobival määral oma eluga seotud moraalsete otsuste tegemises osalemine.

2. Kaitstus ja turvatunne. Hirm ja ebaturvalisus suurendavad haavatavust. See hõlmab ka hirmu isikliku turvalisuse pärast. 
Fattore, Masoni ja Watsoni (2007) uurimuses kirjeldasid lapsed haavatavust suurendavana just hirmu isikliku turvalisuse pärast, eriti üksindusehirmu ning hirmu langeda kuriteo ohvriks, ent ka hirmu ja abitust globaalsete sündmuste ees nagu sõda, terrorism ja looduskatastroofid. Turvatunnet suurendavatena nimetasid lapsed teiste inimestega koos olemist, vanemaid, kes neid kaitsevad ja hästi kohtlevad, turvalist kohta, kus olla, ning religiooni. Lastele valmistas muret vanemate mure laste turvalisuse pärast ning sotsiaalses elus osalemise võimaluse piiratus füüsilise keskkonna ebaturvalisuse tõttu.

3. Lapse "mina". "Mina" all mõeldakse negatiivset või positiivset tajumust endast. Haavatavust suurendab lapse "minale" negatiivselt mõjuv väheväärtuslikkuse tunne ning enda - teistega võrreldes - praegu ja tulevikus mitteaktsepteerituna tajumine. Siia kuuluvad ka n-ö tegevused ja aeg iseendale, mis aitavad luua head enesetunnet.

Fattore, Masoni ja Watsoni (2007) leidsid, et laste silmis näib minapilt olevat seotud reflektsiooniga interaktsioonis endale oluliste teiste isikutega (sõbrad, perekond). Samas pole tegu lihtsalt kahepoolse protsessiga. Lapse "mina" interaktsioonis ümbritsevatega on oluline osa lapse agentsusel, mille kaasabil laps eristab oma erinevusi ja sarnasusi võrreldes oluliste teistega. Lapsed kirjeldasid ka "sisemise töö" olulisust heaolu tajumisel (haavatavust vähendava tegurina). "Sisemise tööna" kirjeldasidki lapsed aega, tegevust ja ruumi, mida nad tajuvad endale kuuluvana (mille käigus on võimalik läbi töötada muljeid, läbielamisi, mis kuhjudes võiksid psüühiliselt koormavaks osutuda).

4. Materiaalsed ressursid. See sfäär hõlmab laste hinnanguid selle kohta, kuidas materiaalsete ressursside olemasolu/puudumine mõjutab nende haavatavust.

Fattore, Masoni ja Watsoni (2007) uurimistulemuste järgi olid lapsed teadlikud, et raha annab suurema ligipääsu kultuurilistele tegevustele ja kultuurilisele kapitalile. Kuigi lapsed tajusid raha olulisust haavatavust vähendava/ heaolu suurendava faktorina, tõusis peamise asjaoluna raha ja haavatavuse/ heaolu vahelises seoses esile osutus, et laste meelest on vajalik "küllalt raha", et tagada oma perekonna piisav elatusstandard. Lastele valmistas muret, kui nende pere "tuli ots-otsaga kokku". Osa lapsi olid mures selle pärast, kuidas vaesus mõjub nende ülejäänud pereliikmetele ning rääkisid vaesusega seonduvast häbist. Mõne lapse silmis olid tähtsal kohal haavatavust vähendavad emotsionaalselt olulised esemed, mille aineline või majanduslik väärtus võis olla vähene. 
5. Füüsiline keskkond ja kodu. See sfäär hõlmab asjakohase turvalise ja last erinevates aspektides toetava füüsilise ruumi olemasolu või selle puudumist, eelkõige turvalist kodu, isiklikku ruumi oma kodus.

Fattore, Masoni ja Watsoni (2007) järgi suurendab laste turvalisust oluliselt see, kui nad saavad autonoomselt ja ohutult kasutada erinevaid vaba aja tegevusteks mõeldud paiku, kui nad tunnevad end turvaliselt igapäevaselt nt õues, parkides mängides. Lastele on turvatunde jaoks keskse tähtsusega kodu, kus saab perega koos olla, oma põhivajaduste eest hoolitseda, lõõgastuda, olla "mina ise".

Fookusgruppide analüüs on esitatud nimetatud viie sfääri lõikes ning intervjuude transkriptsioonides on esile toodud esinenud laste haavatavuse aspektid ja tsitaatidena esitatud näited laste jutust.

\section{Metoodika ja andmekogumismeetod}

William A. Corsaro (2015: 4) on esile toonud, et lapsed konstrueerivad ise oma sotsiaalset tegevust ja lapsepõlv on eraldiseisev strukturaalne osa ühiskonnast. Lähtudes kaasaegsest lapsepõlvesotsioloogia printsiibist, et lapsed on oma elu asjatundjad ja aktiivsed toimijad (Mason \& Hood 2011: 490), on käesoleva uurimuse andmekogumismeetodiks poolstruktureeritud fookusgrupi intervjuu, mille kaudu said lapsed esitada ise oma mõtteid ja kogemusi oma elu kohta. Mikrotasandi meetodi kaudu, nagu seda on fookusgrupi intervjuu, saavad lapsed aidata täiskasvanuil tundma õppida sotsiaalseid nähtusi läbi nende enda elukogemuse, seletada laste perspektiivist, kuidas lapsed tulevad toime täiskasvanute kehtestatud reeglite ja ühiskondliku tegelikkusega (Corsaro 2015: 49).

Lastega läbi viidava uurimistöö väljakutseks on vajadus ületada/minimeerida lapse-täiskasvanu positsioonide hierarhilisust uurimisolukorras, et mitte teha täiskasvanu positsioonilt oletusi laste kompetentsuse, haavatavuse ja kogemuste kohta (Moore 2015). Laste haavatavuse/SH käsitlemise normatiivseks aluseks on laste enda konstrueeritud haavatavus/SH ning seejuures on vaja arvestada konteksti, milles need sotsiaalsed konstruktsioonid on välja arenenud (Fattore \& Fegter \& Hunner-Kreisel 2018). Avatud, paindlik ning laste arvamust austav ja väärtustav intervjuuõhkkond oli seatud eesmärgiks kõigi nelja fookusgrupi toimumise puhul.

Laste agentsuse ja laste enda kogetu ning selle tõlgenduste arvesse võtmiseks on käesolev uurimus läbi viidud kvalitatiivset uurimisviisi kasutades. Kuna sotsiaalne, emotsionaalne ja kognitiivne areng mõjutab viisi, kuidas infor- 
mant käsitleb uurimisolukorda (Deatrick \& Faux 1991), käitusid intervjueerijad lastega kui võimalikult võrdväärsete vestluspartneritega. Viimati nimetatut arvesse võttes viidi andmekogumine läbi koolides lastele nii harjumuspärases keskkonnas kui võimalik kõrvalistest isikutest eraldi asuvas ruumis, järgides asjakohaseid uurimistöö eetilisi põhimõtteid (informantide õigus rääkida vaid neile sobivatel teemadel; intervjuude konfidentsiaalsus; analüüsitulemuste esitamine lahus konkreetsetest intervjuudes osalejatest/õppeasutustest; andmete kasutamine vaid käesoleva uurimuse / ISCWeB kvalitatiivse uurimistöö raames). Kuna lastel ei pruugi olla kogemust, et täiskasvanud kohtlevad neid kui võrdväärseid, mistõttu nad võivad tunda end suhtlemisel mittetuttava täiskasvanuga ebakindlana (Punch 2002), pöörati intervjueerimisel erilist tähelepanu intervjuu kulgemisele laste endi tempos, anti vähem jutukatele lastele võimalus soovi korral vähem rääkida, kuid aktiveeriti neid intervjuu jooksul siiski korduvalt, pöördudes eraldi nende poole teemadel, mille puhul teised lapsed altilt ise kaasa rääkisid. Tundlikke teemasid (lähedase surm, mitteeakohased tegevused jms), mis grupis esile kerkisid, intervjueerijad omalt poolt edasi ei arendanud, et mitte ohtu seada laste privaatsust ja emotsionaalset seisundit. Kuna käesoleva uurimuse eesmärk oli käsitleda iga intervjuurühmaga vestluse käigus kõiki laste eluvaldkondi (lapse mina, sõbrad, kodu, vanemad, kool, materiaalne ja füüsiline keskkond), siis kuigi sügavuti iga konkreetse teemaga ei mindud. Anti võimalus lastel ise tunnetada, mida neile tundub sobiv antud olukorras esile tuua ja mida mitte. Uurimisstrateegia oli otsinguline (eksploratiivne) st intervjuu käigus tõstatati teemad, millele lapsed said reageerida ja rääkida neil teemadel sellest, mis nendele oluline on. Näiteolukordi/juhtumeid, millega õpilased oleksid saanud nõustuda/ümber lükata, küsimustena ei esitatud.

Iga intervjuu kestis ligikaudu 45 minutit ehk üks koolitund. Ühelt poolt oli see lastele harjumuspärase pikkusega periood, mille jooksul tähelepanu keskendamisega nad on harjunud, teiselt poolt sobis ühe koolitunni pikkune vestlus ka kooliprogrammiga. Mitme kooli kontaktisikud mainisid, et õpetajad ei raatsi oma tunde intervjuuks anda, sest nende programm on üsna tihe ja tundide loovutamine intervjuule segaks oluliselt õppetöö rütmi. Viimati mainitu võib olla ka põhjuseks, miks suhteliselt vähesed koolid uuringu läbiviimise pöördumisele vastasid. Seda suuremat tänu väärivad õpetajad, õppejuhid, direktorid, kes olid valmis aega leidma ning aitasid oluliselt kaasa käesolevaks uurimuseks vajalike andmete kogumisele. 


\section{Intervjuudes osalejad}

Uurimuses osalesid nelja eestikeelse üldhariduskooli kuuendate klasside õpilased. Valdav osa õpilasi fookusgruppides olid 12-13aastased. Sooline jaotumine kõigi intervjuude peale kokku oli 9 poissi ja 16 tüdrukut. Autor viis uuringu läbi neljas koolis, millest üks oli Tallinna kool, kaks maakonnakeskuste kooli (erinevates maakondades) ning üks väike maakool, mis asus linnast väiksemas asulas. Selline koolide valik võimaldab anda parema ülevaate Eesti õpilaste haavatavuse aspektide kohta, kuna võttis arvesse erinevate sotsiaalsete keskkondade mõjusid.

Intervjuurühmade moodustamisel oli lähtekohaks, et keerulistel teemadel vesteldes on soovitav fookusgruppi kaasata kuni seitse liiget (Kruger 1994), et igale grupiliikmele jätkuks parajalt tähelepanu ja piisavalt aega enda väljendamiseks ning samas avalduks ka rühma liikmetevaheline sünergia (grupidünaamika), mis mõjub toetavalt eneseväljendusele (Parker \& Tritter 2006: 29).

Kolme intervjuu (fookusgrupid 1-3) tegemisel oli uuringu autorile lisaks kaasatud ka (naissoost) abiintervjueerija, kelle ülesandeks oli intervjuuolukorra dünaamika tasakaalustamine (neljandal intervjuul ei saanud abiintervjueerija osaleda ning intervjuu viis läbi autor üksi).

Esmase nõusoleku fookusgruppides osalemiseks andsid koolid, kelle poole vastava taotlusega pöörduti, kuid lõpliku osalemisotsuse pidid andma lapsevanemad ning lapsed ise. Pöördumisi fookusgrupiintervjuu läbiviimiseks käesoleva uurimuse raames esitati 18 koolile üle Eesti, sellele vastas viis kooli. Intervjuu toimus neljas koolis, viienda kooli juht andis teada, et nende koolis õpib kuuendas klassis ainult kaks õpilast. Koolile esitatud infos sooviti moodustatava intervjuugrupi suuruseks 5-6 õpilast. Õpilaste valikul rühmadesse oli mõningatel juhtudel suur osa õpetajatel (kui õpetaja tegi õpilaste valiku), teistel juhtudel õppejuhtidel (juhul kui kooli kontakt- ning vastutav isik oli kooli õppejuht). Uuringu autor ei soovinud koolidele lisaks rühma suurusele täiendavaid kriteeriume esitada, kuna koolide aktiivsus uuringupöördumistele vastamisel oli madalavõitu (22\%). Tallinna fookusgrupi puhul sõlmiti õpetaja initsiatiivil kokkulepe, et rühma valitakse võrdselt nii poisse kui ka tüdrukuid, nii õppimises edukamaid kui ka vähemedukaid õpilasi. Ühe maakonnakeskuse grupi moodustamisel saadi õppejuhilt nõusolek ja kokkulepe, et intervjuul osalevad lisaks tüdrukutele ka poisid, kuid intervjuu toimumise päeval poisid paraku puudusid koolist (see oli ainus vaid tüdrukutest koosnev rühm). Teise maakonnakeskuse fookusgrupi puhul konsulteeris õppejuht eelnevalt autoriga, kas grupis võiksid esindatud olla ka poisid. Kaks poissi sellesse intervjuusse ka kaasati. Maakooli intervjuul oli grupis õpilasi kümme (sh poisse ja tüdrukuid võrdselt), kuna direktorile oli jäänud mulje, et intervjuus saavad osaleda 
kõik õpilased, kellelt oli nõusolek intervjuuks olemas. Kooli koostöövalmidust tunnustades sai viimati nimetatud fookusgruppi kaasatudki kümme õpilast. Sama klassi õpilaste intervjueerimine ühes rühmas loob õpilastele turvalisema ja toetavama õhkkonna (Hill et al. 1996). Vastavalt sellele printsiibile said käesolevas uurimuses intervjuurühmad ka moodustatud.

Kuna eelnevalt põhimõttelise osalemisnõusoleku andnud õpilaste valik rühmadesse oli koolitöötaja otsustada, siis tõenäoliselt valisid nad igasse rühma muuhulgas aktiivseid ja jutukaid lapsi, kes kaldusid intervjuudes domineerima. Valdavalt olid aktiivsemad grupiliikmed tüdrukud, vaid ühes grupis poisid. Ideaalis oleks parem olnud intervjueerida aktiivsemaid ja vähemaktiivseid ópilasi ning poisse ja tüdrukuid eraldi. Kuna aga koolide valmidus uuringus osaleda oli napp, siis polnud selline erinevat tüüpi gruppide moodustamine võimalik. Kuna intervjuude kestus oli ajaliselt küllaltki piiratud, ei jätkunud nende ajal üldiselt võimalusi vähemaktiivsete õpilaste aktiveerimiseks (kuigi intervjueerija andis neile peaaegu igal teemal eraldi võimalusi teiste vahelesegamiseta ennast väljendada). Sellest tulenevalt olid intervjuudes rohkem esindatud tüdrukute ning aktiivsete ja jutukamat tüüpi laste eluolukorrad, seisukohad, vaated. Andmete analüüsil on siiski lähtutud teemadest, mis kataksid kõiki olulisi lapse elu valdkondi (vt lõiku "Laste elusfäärid: tüpoloogiline mudel") ning kõigi laste ütluseid on analüüsil käsitletud võrdselt vastavalt nende kvalitatiivsele iseloomule.

Intervjuud viidi läbi oktoobrist 2018 kuni märtsini 2019. Autor omalt poolt koolidele tagasisidet intervjuude kohta ei pakkunud, ja koolid selleks ka ise soovi ei avaldanud. Kolme kooli esindajad mainisid otsesõnu, et nende põhimõtete hulka kuulub õpilastele uurimustes osalemise kogemuse pakkumine ja uurijatele andmete kogumise võimaldamine. Ühe kooli puhul oli õpetaja uurija tuttav, teisel juhul tuttava tuttav. Viimasel juhul möönis kooli õppejuht, et ega kool ja õpetajad õpilaste heaolu kujundavatest faktoritest kuigi palju tea. Ülejäänud kolme kooli puhul kooli esindaja uuringu teemat ei kommenteerinud. Esialgne uuringu tutvustusleht sai saadetud kas direktori või õppejuhi e-mailile. Esimesele e-mailile oli lisatud ka ühiselt lapsevanematele ning õpilastele endile mõeldud uuringut tutvustav ja osalemiseks nõusolekut küsiv pöördumine. Uuringu alguses tutvustasid intervjueerijad osalejatele uurimuse eesmärke ning kordasid üle põhimõtted andmete konfidentsiaalsuse ja üldistatud kujul esitamise kohta.

Üldiselt tulid õpilased intervjuu teemade ja küsimustega hästi kaasa. Kõigis intervjuudes said kõik eelnevalt planeeritud teemad käsitletud. Küll aga said erinevates intervjuudes poolstruktureeritud iseloomu tõttu erinevad teemadegrupid erineval hulgal tähelepanu. Igas rühmas oli nii õpilasi, kes tundsid ennast intervjueeritavatega vesteldes küllaltki vabalt, kui ka neid, kelle puhul 
oli tajutav, et nad tundsid ennast intervjueerijaga võrreldes olevat oluliselt ebavõrdsemas positsioonis. Intervjuude algupoolel oli märgata, et õpilased püüdsid tabada n-ö õiget vastust - sellise dünaamika esinemisele on viidanud ka Punch (2002: 336). Nimetatud olukorras selgitati lastele, et kõik seisukohad ja arvamused on õiged, ja julgustati neid rääkima, samas veel kord rõhutades, et kui nad tõesti ei soovi mõnel teemal rääkida, siis on neil vaba valik seda mitte teha.

\section{Andmeanalüüsimeetod}

Andmete analüüsimisel on autor kasutanud modifitseeritud temaatilise analüüsi mudelit (Braun \& Clarke 2006; st kuuefaasiline temaatilise analüüsi raamistik (faas 1: andmetega tuttavaks saamine, faas 2: algsete koodide loomine, faas 3: teemade otsimine, faas 4: teemade üle vaatamine, faas 5: lõplikud teemad, faas 6: tulemuste kirjapanek)). Erinevus puhtalt lehelt alustatava temaatilise analüüsiga on antud juhul see, et Virginia Brauni ja Victoria Clarke'i (2006) analüüsiskeemi faasi 2 ehk algsete koodide loomise asemel on algseteks koodideks võetud Tobia Fattore, Susann Fegteri ja Christine Hunner-Kreiseli (2019) poolt kvalitatiivse uurimisviisiga leitud viis lapse haavatavust/heaolu mõjutavat elusfääri. Nimetatud viie elusfääri lõikes on edasistes analüüsifaasides leitud vastavad alateemad. Fattore, Fegteri ja Hunner-Kreiseli (2019) tüpoloogia on võetud aluseks, kuna see võimaldab luua võrdlusaluse analoogse varasema materjaliga.

Temaatilise analüüsi eesmärgiks on avada andmestikus nii nähtavad kui ka varjul olevad tähendused ja seisukohad (Ezzy 2002: 86) ning teemade analüüsil arvesse võtta kogu andmestikku kui tervikut (Braun \& Clarke 2006: 91-92). Nimetatud temaatilise analüüsi 2. faasis (algsed koodid) kasutati Fattore, Fegteri ja Hunner-Kreiseli (2019) lapse elusfääri viit suurt domeeni (tutvustatud allpool). Teemade ülevaatuse (4. faas) järel on lõplike teemadena (5. faas) leitud intervjuu transkriptsioonidest suurte domeenide alateemade kaupa laste haavatavuse aspekte avavad andmed koos illustreerivate tsitaatidega laste jutust. Tulemuste esitamisel peeti oluliseks rohke illustreeriva materjali esitamist tsitaatide näol, sest autor leiab, et laste endi esitatuna ja väljendatuna on see uuringutulemuste oluline kvalitatiivne lisaväärtus (võimaldab saada ettekujutuse laste mõtteviisidest ja maailmakäsitlusest). 


\section{Tulemused}

Uuringutulemused on esitatud Fattore, Fegteri ja Hunner-Kreiseli (2019) tüpoloogia alusel, mis eristab lapse elusfääride kaardistamisel viit suurt domeeni, mille lõikes on esitatud ka analüüsitulemused. Intervjuu tsitaatide esitamisel on kasutatud intervjuudes osalenute anonüümsuse tagamiseks järgmisi lühendeid: $\mathrm{P}$ - poiss, $\mathrm{T}$ - tüdruk, FG - fookusgrupi number. Linnu ja asulaid, kus intervjuudes osalenud koolid asuvad, ei ole andmete turvalisuse huvides ära toodud. Analüüsi jaoks mitteolulised lõigud, mis on tsitaatidest välja jäetud, on märgitud järgmiselt: [---].

\section{Autonoomia ja agentsus}

Kahe intervjuu puhul tuli välja laste agentsuse küsimus juba seoses käesoleva uuringu tutvustusega, mis oli mõeldud õpilastele ja nende vanematele. Kuigi uuringut tutvustav tekst oli mõeldud ka lastele endile tutvumiseks, siis see lasteni ei jõudnud. Uuringut tutvustav tekst oli vormistatud eraldi PDF-ina, millest üks eksemplar oli mõeldud koolile (õpetaja, õppejuht või direktor), teine lapsevanematele ja õpilastele. Üks poiss küsis:

Õpilane (P): Mis selle küsitluse mõte on? Me nagu... mitte ükski ópetaja ei suutnud ära seletada. Mis me tegema peame? (FG2)

Pärast seda küsimust seletas autor uuringu idee ja eesmärgi ammendavalt lahti. Selle käigus selguski, et klassijuhataja ei olnud põhjalikku selgitavat teksti, mis oli ka lastele mõeldud, neile edasi saatnud. Otsesõnalist instruktsiooni, et õpetajad või lapsevanemad tutvustava teksti ka lastele peaksid edastama, uuringu autor andnud ei olnud ja see andis võimaluse näha, kuidas nad harjumuspäraselt taolises olukorras käituvad. Kuid vanematele ja lastele mõeldud põhjalik tutvustustekst oli siiski pealkirjastatud vastavalt "Tere, head lapsed ja lapsevanemad!", osutades, et see on adresseeritud ka lastele. Fookusgrupi 2 (FG2) lapsed ütlesid, et neile seda teksti keegi näidanud ei ole. Ka fookusgrupi 3 (FG3) lapsed ütlesid, et tutvustavat teksti neile ei edastatud. FG2 õpilased tõstatasid selle küsimuse ise. FG3-s küsis intervjueerija õpilastelt, kas nad tutvustuse said. Ülejäänud kahes intervjuus (FG1 ja FG4) see teema jutuks ei tulnud. Kahe fookusgrupi näitel tuli välja, et kool ega vanemad ei kaasanud kuigi põhjalikult lapsi arutelusse neid puudutavate otsuste üle (laste vähene agentsus). Kuna intervjuu kestvus oli küllaltki piiratud, siis selgitas intervjueerija intervjuu alguses selle tausta pigem skemaatiliselt (eeldades, et varasemas kirjalikus materjalis oli seda juba põhjalikumalt tehtud). 
Teisalt aga ilmnes, et ühes koolis (FG2) oli õpilaste agentsus igapäevasuhtluses õpetajatega hoopis teisel tasemel kui see ülejäänud koolide puhul intervjuudest välja tuli. FG2-s rääkisid lapsed, et neil on õpetajate ja ka kooli direktoriga üsna vahetu kontakt. Tegemist oli osalenud koolidest kõige väiksemas asulas asuva kooliga.

Õpilane (P): Aga kooli poolest on meil hästi vedand, sest meil on hästi lahedad õpetajad siin, sest ma kuulen, mis [lähimas linnas] õpetajad teevad ja ma vaatan meie õpetajaid siis... direktor suhtleb hästi vabalt meiega ja kehalise õpetaja sama moodi ja.. (FG2)

FG3 toimus koolis, kus õpilastel on kohustuslik koolivorm. Õpilased ütlesid, et neile see ei meeldi (nt õpilane (T): "Aga ei meeldi, et on koolivorm.” (FG3)). Koolivormi kohustuse kehtestas kool lapsevanematele nõusolekul ja koolivormi värve said valida samuti laste vanemad. Laste arvamust ühes ega teises küsimuses kool ei küsinud.

Intervjuudes selgus, et paljudel õpilastel on vähe vaba aega, mida nad täiesti ise planeerida ja sisustada saavad. Hõivatumad õpilased olid koolist ja huviringidest vabad vaid ühel päeval nädalas. Kas suure hulga huviringe oli valinud pigem laps ise teataval vanematepoolsel või sotsiaalsel survel ning konkurentsi tajudes, ei tulnud laste jutust välja. Mõnel konkreetsel juhul ei olnud huviringid laste enda valitud, vaid lapsevanemate nägemus lastele vajalikust. Mõnel juhul oli lastel vanematega kokkulepe, et nad saavad käia enda valitud huviringis siis, kui nad lisaks sellele käivad ka vanema valitud ringis.

Õpilane (T): Mul on see, et kui ma jätan muusikakooli ära, siis ma pean jätma ratsutamise ka ära. Vanematega kokkulepe. (FG3)

Kooliga seoses tõid lapsed esile tihedat programmi ja selle väsitavat iseloomu ning et õpetajad on õpilastega suheldes närvilised. Jäi mulje, et õpilased ei mõista sageli, miks peavad asjad koolis just antud kindlal moel korraldatud olema ja miks ei võiks õpilastel olla rohkem kaasarääkimise õigust. Intervjueerija küsimusele, mida õpetaja siis ütleb, kui avaldate soovi asju teisiti teha, vastasid lapsed näiteks, et: "Õpetaja ütleb, et tal on selline programm ees ja ta ei saa siin midagi muuta” (FG1). Õpetaja selline väide annab lastele signaali, et ka õpetaja autonoomia ja agentsus pole koolis alati teab kui suur ning selline ühine teadmine võib küll tekitada õpilaste ja õpetajate vahel teatud solidaarsustunnet, kuid kool on oma üldiselt tiheda ja ettekirjutatud programmiga pigem vähest autonoomsust võimaldav institutsioon.

Õpilane (T): Väsitav võib öelda... viimasel ajal nagu.

Õpilane 2 (T): Hästi palju kontrolltöösid on! (FG4) 
Õpilane (T): [---] mõned lähevad selliseks hästi kurjaks, hästi väikeste asjade peale närvi ja.. (FG4)

Õpilaste "mina" eneseväärikuse seisukohast on haavatavust vähendav aspekt see, et isegi kui neil on mõne õpetajaga probleeme, siis kool kuulab nende mure ära ja õpilaste häält õppetöösse puutuva osas võetakse arvesse.

Õpilane (T): Me oleme seda teinud! [Esitanud kaebuse õppealajuhatajale õpetaja kohta]

[---]

Õpilane 2 (T): Ma ei tea, sest pole väga midagi muutunud. Teised klassid ütlevad, et ta pole nii range. [---] aga seal tunnis oleme me kõige vaiksemalt minu arust. (FG4)

\section{Kaitstus ja turvatunne}

Intervjuudest ilmnes, et haavatavust vähendab see, kui lähedastega on kõik korras ja kodus saab ennast hästi tunda, sõpradega aega veeta.

Õpilane (P): [Sõpradega] koos olemine (FG2)

Õpilane 2 (P): See ka, et kodu on turvaline ja... (FG2)

Teemal "Mis lapsi häirib elus?" mainiti koolikiusamist (poiss, FG2). Ühes intervjuus (FG4) rääkisid lapsed, et nende klassis on ühte poissi regulaarselt kiusatud. Lapsed ütlesid, et kui see oleks nende võimuses, siis "kiusamine ja selline jääks ära!". Kiusamine klassikaaslaste vahel häirib kogu klassi õhustikku. Positiivsena toodi FG4-s välja, et õpetajad ja direktor on nimetatud kiusamise juhtumiga tõsiselt tegelenud, mis suurendas laste kindlustunnet, ning ükski intervjuus osaleja isiklikult kiusamise all kannatanud ei olnud.

Õpilane (T): See kõik läks nagu paremaks.. kui direktor ja vanemad kõik pidid tulema kooli ja nad pidid ilgelt rääkima ja kõik omavahel. (FG4)

Mis puutub turvatundesse laiemal ühiskondlikul tasandil, siis valdav osa lapsi mainis, et nad üldiselt jälgivad (päeva)uudiseid. Globaalsema mõõtme turvalisuse aspektis annab üldine meedia vahendatud maailmasündmuste foon, mida lapsed tajuvad ja mille puhul intervjueeritavad tõid välja erinevaid ebaturvalisust suurendavaid sündmusi, nagu erinevad militaarkonfliktid, onnnetused, keskkonnaga seotud probleemid.

Õpilane (P): Kindlasti on sõjad ja need... need on... jubedad (FG2)

Õpilane 1 (T): Või on keegi... mingi õnnetus-uudis. [---] Need lennukid, 
mis on juhtunud, neid ma...

Õpilane 2 (T): Ekstreemsed... kui üks lennuk alla kukkus... [---] (FG3)

Muuhulgas nimetasid lapsed asjadena, mida nad maailmas “ära parandaksid”, kui see oleks nende võimuses, erinevaid globaalseid ja sotsiaalseid probleeme. Laste silmis suurendab turvatunnet sotsiaalse õigluse tajumine. Ebavõrdsus ning asotsiaalsus on lastele raskesti mõistetavad ja tekitavad ebamugavustunnet.

Õpilane (T): Et riikide vahel oleks rahu! [---] Ma tahaks nagu seda, et mu isa käis Ameerikas ja ta just rääkis mulle, et kuidas ta mõtles sellele, et ta nägi hästi palju kodutuid seal Ameerikas, et kuidas nemad on halvemad kui tema, [---] nemad peavad passima seal samas ja kerjama raha... et kui minust oleneks, siis kodutuid ei oleks, et kõigil oleks oma kodu.. [---] (FG4)

FG4 lapsed, kes andsid oma elule üldise õnnelikkuse hinnangu vahemikus 7...9 (grupis oli kuus last, hinnang oli antud skaalal $0 \ldots 10$, kus 0 oli "täiesti õnnetu" ja 10 “täiesti õnnelik"), tõid välja, et kuigi nad tunnevad homse päeva suhtes kindlustunnet, et midagi halba ei saa "maailma asjade peale mõeldes" juhtuda, siis ometigi on teatud oht olemas.

Õpilane 1 (T): Väga kindel [et homme on jälle selline ilus päev ja midagi halba ei juhtu].

Õpilane 2 (T): Jaa, kindel, aga samas see võib niimoodi nipsuga tulla, et... ptüi, ptüi, ptüi, vaata, et... aga praegu suht kindlalt, et midagi ei juhtu.. (FG4)

Häirivana tõid lapsed esile mitmeid meedia vahendatud teemasid või toimimisja käsitlusviise, millega seoses neil tekivad vastuseta küsimused, arusaamatus (psühholoogiline pinge) maailmas toimuva suhtes.

Õpilane (T): Minu meelest võiks "Kuuuurija" teha mitte nii rõvedaid saateid. Kui nii rääkida nii rõvedatest asjadest.. [---] saatejuht läheb teiste kodudesse, lihtsalt tungib. (FG1)

Õpilane (T): Kui ma viimati lugesin seda [ajakirja Ajalugu], siis seal oli, et [---] tahetakse välja selgitada, mis... miks need jalad ära lõigati ja kuidas... eee... (FG1)

Negatiivselt mõjuvana tõid lapsed esile valimiskampaaniad ja poliitikute käitumise, kartuse, et poliitikute tehtud otsused võivad kohati olla põhjendamatud. Lapsed kirjeldasid poliitikute võimu teostamist kui ettearvamatut protsessi ning viitasid ka potentsiaalsele seadustega ülereguleerimisele. 
Õpilane (T): Luuletavad kõike... need poliitikud kokku! (FG2)

Õpilane (P): [---] nad võtavad igalt poolt tasuta neti.. WIFI.. mis nad veel ära võtavad? Kõik asjad keelavad Eestis ära ja siis viskavad rohelist värvi maha. (FG2)

Ebaturvalisust tekitab osades lastes sotsiaalmeedia kasutamine, kuna nad pole kindlad, kas info (ka eravestlused ja mitteavalik info), mida nad seal jagavad, on võõraste eest kaitstud või mitte.

Õpilane (T): Seal on mingid inimesed kuulavad, et saada informatsiooni, et mis reklaame teha. Ja mingid kaamerad on seal ja ma ei tea.. Minu arust Facebook ei ole üldse usaldusväärne koht, aga nagu.. Messengeris on vahest tore sõpradega rääkida. Näiteks nädalavahetusel või siis peale kooli kui nagu kokku ei saa. (FG1)

Valdavale osale lastest oli nende sõnul tavapärane viibida erinevates veebi suhtluskanalites 4-5 tundi päevas. Kõige pikema keskmise päevase suhtlusvõrgustikes viibimise aja tõi välja üks tüdruk: 9-10 tundi ööpäevas (FG4). Seega on sotsiaalmeedia mõjusfääris viibitud aeg ööpäevas proportsionaalselt arvestatava suurusega. Suur osa õpilastest hindas oma veebis veedetud aega ise liiga pikaks. Õpilased mainisid, et neid häirib kohati ka teadmine, et veebi kaudu võivad inimesed esineda kellegi teisena ja neile mittesobivatel teemadel suhtlust alustada.

Õpilane (T): [---] “Pealtnägijas” oli ükskord selline asi, et [---] Growtopia.. see, millest ma enne rääkisin ka.. seal oli nagu... mängusiseselt oli nagu mingi võõras pervert oli kutsunud 18+ asja tegema.. [---] see... oli nii kahtlane, et ma olen seda mängu mänginud.. (FG1)

Samas fookusgrupis kirjeldavad õpilased, et üks nende klassiõde saadab juhuslike veebikontaktide kaudu temani jõudnud alastipilte edasi kogu klassi või klassi tüdrukute gruppi. Lapsed ei analüüsinud ega selgitanud täpsemalt, milliseid reaktsioone see neis tekitab, aga ilmselgelt oli tegemist mitte-eakohase ja suure tõenäosusega neid häiriva temaatikaga. Veebisuhtlus kätkeb endas suuremat ettearvamatust ja ootamatuid suhtlusprobleeme, mis arvestades veebis veedetud aja suurt hulka on väga oluline mõjutegur laste turvalisustundele.

Õpilane (T): Ja siis hakkavad rääkima ja saadavad igasuguseid alasti pilte... siis [---] [saadab] meile Messengeri meie klassi gruppi või tüdrukute gruppi [---] (FG1)

Väljavaade kooli vahetamisest ja suuremasse kooli minekust tekitas lastes teatud ärevust ja küsimusi, kuidas nad seal kohanevad. 
Õpilane (P): Aga mõnes mõttes on mul hirm ka, et kui me siin oleme nagu oppetajatega ühel tasemel, siis seal koolis on see, et me oleme alandlikud opetajale, et õpetaja on keegi kõrgem. Me suhtleme nagu nii vabalt õpetajatega (FG2)

Koolivahetusest rääkisid lapsed ka ühes teises fookusgrupis (FG3), kuid seal koolivahetusega seotud hirme või ebameeldivusi ei mainitud. FG3-s nimetati, et kooli vahetamine võib olla teatud määral probleem, kui õpilane ei leia uues koolis piisavalt häid sõpru, kuna head sõbrad loovad turvalisema õhkkonna.

\section{Lapse "mina"}

Lapsed tõid esile, et neis tekitab parema, suurema enese väärtustamise tunde väiksem klass, ja ka väiksemate koolide õpilased ütlesid, et neil on seal kaaslastega (nii kaasõpilased kui õpetajad) parem kontakt. Suuremate klassidega suuremast koolist väiksemasse kooli väiksemasse klassi tulnud tüdruk ütles, et uues väiksemas klassis on tal kaaslastega parem kontakt.

Õpilane (T): Siin on toredad inimesed. Seal oli suur klass ja keegi kellegagi väga ei suhelnud. Ma ei tea... Kõik olid nagu oma pundiga eraldi. (FG3)

Lapse "mina" arengule mõjub soodsalt, kui laps saab ise oma tahet otsustes realiseerida ning ilmselt tuleb kasuks ka see, kui laste ja vanemate vahel toimub arutelu, mille käigus saavutatavates kokkulepetes arvestatakse ka laste arvamusega. Mõned lapsed möönsid muuhulgas, et ega nad ei pruugigi ise alati teada, mis neile kõige parem on (FG3-s), ja teatud määral võib suunamine kokkuvõttes lapse "mina" arengut toetada. Kuigi samad lapsed, kes väitsid, et ehk nad ei oskakski ise alati õigeid valikuid teha, ütlesid, et nad tegelevad mõne huvialaga ainult vanemate nõudmisel. Juhul kui lapse refleksioon ja "läbirääkimised" suhtluses vanematega jätavad lapsele alles positiivse minapildi, võib ka vastu lapse tahtmist täidetud kohustusi lugeda haavatavust vähendavateks (konkreetse lapse ja vanema interaktsioon oleneb paljuski individuaalsetest eripäradest).

Õpilane (T): Mul kestab (muusikakool) neli aastat. Kohe saab läbi. See on viimane aasta.

Intervjueerija: Siis saad valida juba muud.

Õpilane (T): Jaa.

Õpilane 2 (T): Me ainult praegust ütleme nii. Me tegelikult ei tea. Aga lihtsalt... (FG3) 
Õpilane (T): Me oleme seda teinud! [Esitanud kaebuse õppealajuhatajale õpetaja kohta] [---]

Lapsed tõid esile ka juhtumeid seoses tõrjutusega, kuid möönsid, et need on olnud pigem ajutised arusaamatused kui midagi tõsist ja püsivat. Nimetatud teema tuli jutuks seoses ühiste sotsiaalmeedia gruppidega, kus osa grupiliikmeid tundis ennast ühistest tegevustest eemalejäetuna.

Õpilane (T): Jaa, hästi palju on selliseid välja jätmisi ja nendega on ka igasugu jamasid. (FG4)

Iga intervjuu puhul said lapsed rääkida, mis sündmus(ed) neile elus on viimasel ajal elamuslikud olnud. Enamasti väljendasid laste vastused eneseväärtustamise tunnet seoses kirjeldatud elamusliku sündmusega. Elamuslikud sündmused olid muuhulgas sõprade või perega koos ajaveetmine, hobide ja reisimisega seotu. Aga oli ka õpilasi, kes ütlesid elamusliku sündmuse kohta, et nad ei oska ühtegi (meeldivat) elamust nimetada. Õpilased, kes ei osanud hiljutisi elamusi nimetada, olid poisid, kes olid võrreldes teiste intervjuus osalenud lastega üldse vähem jutukad.

Õpilane (P): Ei tea... (FG4)

Õpilane (P): Mul praegu ei ole mingit elamust olnud. (FG1)

Küllaltki üksmeelselt ütlesid lapsed kõigis intervjuudes, et neile annavad hea enesetunde sportlikud tegevused (kergejõustik, sportmängud, suusatamine, ratsutamine). See on laste kvaliteetaeg iseendale ning aitab välja lülituda muudest teemadest/mõtetest.

Lastes tekitas segadust ja häiritust õpetajate ebaloogiline käitumine, millele ei osata seletust leida. Näiteks annab mõni õpetaja õpilaste sõnul laste tegevusele hinnanguid ilma ammendava selgituseta, millest lähtuvalt ta seda teeb.

Õpilane (T): [---] onju, ja ma tõstan tunnis kätt ka ja proovin vastata ja siis just õpetaja ei võta mind.. nagu.. nagu.. minu arust üldse õpetaja.. kui ma tõstan kätt, siis õpetaja ei küsi mind. [---] Ja siis kui ma ei tõsta, siis ütleb vanematele, et ta ei tõsta üldse kätt tunnis [---] (FG1)

"Mina" ja isiksuslikku arengut puudutavana kerkis laste ütlustes esile laste isadega seotud teema. Mitmed intervjuudes osalenud lapsed ütlesid, et nad arutavad olulisi asju põhiliselt emaga. Mitmed lapsed elasid oma päris isast lahus koos emaga.

Õpilane 1: Mu ema ja isa ei suhtle nii palju enam.. kui varem. Ja see on kurb.

Õpilane 2: Ma ei suhtle üldse oma isaga. Et see veits nagu häirib (FG4) 
Laste ja nende isade teema sügavamat käsitlemist ei leidnud, kuid analüüsi käigus paistis eraldi silma, et lapsed nimetasid korduvalt halbu suhteid isaga ebameeldivaks asjaoluks nende elus. Samas olulisi vestlusi ja arutelusid pidasid lapsed oma ütluste kohaselt emade (ja ka vanaemadega).

Intervjuudest ilmnes, et lapsed ei ole oma otsustustes nii vabad, kui nad soovivad. Vanemad leiavad, et nad peavad ennast realiseerima valdkondades, millega nad hakkama saavad, kuigi lastele endale need tegevused alati ei meeldi.

Õpilane 1 (T): Noo.. me H.-ga käime muusikakoolis. Ja tema käib ka! Õpilane 2 (T): Jaa, ma käin ka! Mina käin vastu tahtmist!

Õpilane 1 (T): Jaa, mina käin ka vastu tahtmist. Mulle aegajalt meeldib seal, aga ma käin oma vanemate pärast seal, sest nemad ütlevad, et kui sulle on mingi anne antud, siis sa pead seda kasutama. Ma käin laulmas ja ma käin ratsutamas. Mulle endale meeldib rohkem ratsutada, kui neid muid asju teha. (FG3)

Lapse seisukohtadega arvestamise/mittearvestamise mõju haavatavusele/ heaolule oleneb paljuski individuaalsetest iseärasustest. Antud juhul tõid lapsed selle küll esile, kuid ei pidanud seda enda puhul suureks probleemiks.

\section{Materiaalsed ressursid}

Materiaalsetest ressurssidest oli intervjuudes otseselt vähe juttu. Siiski mainisid lapsed ära, et elementaarsed vajalikud materiaalsed vahendid on neil olemas. Kaudselt tulid ressursid jutuks mitme lapse jutus, kui oli juttu nt reisimisest või hobidest (nt ratsutamine on ehk intervjuudes mainitud hobidest üks kallimaid). Tüdruk FG3-s unistas oma isiklikust hobusest. Otsesest mastaabist, kui palju kellelgi hobide peale kulub, juttu ei olnud. Ükski laps ei maininud ka otsesõnu, et ta kannataks ainelise puuduse all. FG4-s ütlesid paar tüdrukut, et nende meelest ei peaks üldiselt firmariideid ja tuntud brände üle tähtsustama, et see tekitab pigem asjatuid pingeid inimestes ega muuda elu arvestatavalt paremaks. FG1-s rääkisid lapsed sellest, kuidas materiaalsed vahendid võiksid inimeste vahel võrdsemalt jaguneda.

Õpilane (T): Siis võibolla seda ka et mingi, et maailmas poleks nii tähtsad.. Teised intervjuus osalevad lapsed ütlevad eelmise jutule vahele: Raha! Õpilane (T): Raha! Ja niimoodi, et inimesed vaataks vähem seda, mis firma.. ma ei tea.. riided teisel seljas on. (FG4) 
Ühel poisil oli uue tõukeratta saamine hiljutine oluline sündmus.

Õpilane (P): Mina sain endale eile uue tõukeratta. Käisin seda eile koos sõbraga poest ostmas. Ma olin päris kaua aega tahtnud seda.. mul eelmine oli mingi kolm aastat vana. (FG1)

FG2-s tõid lapsed esile maapiirkondade tasuta ühistranspordi kui nende jaoks positiivse nähtuse.

Kokkuvõttes võib materiaalsete ressursside koha pealt öelda, et lapsed tajuvad raha ja materiaalsete võimaluste olulisust ja tõsiasja, et see võimaldab teatud heaolu suurendavaid tegevusi, kuid samas nad ei tähtsusta seda liialt, ehk normatiivsel tasandil leiavad lapsed, et elu võiks vähem oleneda rahast ja materiaalsete väärtuste sümboolsetest tähendustest.

\section{Füüsiline keskkond ja kodu}

Haavatavust vähendavalt ja heaolu suurendavalt toimib huvialadega tegelemine, näiteks FG2-s tõid mitmed vastajad positiivsena välja sportimisvõimaluse. Maakoolide õpilased tõid esile, et sooviksid paremaid sportimisvõimalusi siseruumides. Paljude laste jaoks oli sport oluline aeg iseendale.

Õpilane (P): Üldse trennid, et saadki ennast argipäeva mõtetest nagu lahti ühendada, et sul ei ole, et sa mõtled nagu.. koolile näiteks (FG2)

Osutati vajadusele rahuliku koduse keskkonna järele.

Õpilane (P): [---] Kõva kisa on lihtsalt see, et mulle ei meeldi lärm. Mul väike vend ka kogu aeg kodus karjub. (FG2)

Ilmnes, et füüsilise keskkonna mõju avaldub infrastruktuuri olukorra halvenemise kaudu maapiirkondades, mis teeb laste silmis nende elu halvemaks.

Õpilane 1 (T): Pood võiks tagasi tulla!

Õpilane 2 (P): Meil pandi 1. jaanuarist pood kinni. (FG2)

Oma kodudest rääkisid õpilased vähe. Mõnel juhul mainiti, et nad peavad oma õdede-vendadega jagama töölauda või mingit osa oma isiklikust ruumist, kuid olulise probleemina seda ei mainitud.

Avalikes kohtades (näiteks õues) viibimise kohta ütlesid lapsed, et tunnevad end turvaliselt. Vajadusel on neil olemas koht, kus õues olla või mängida. Oluline osa lastest ütles, et nad eriti õues ei käi, vaid viibivad õues põhiliselt siis, kui nad kooli või trenni lähevad.

Füüsilise keskkonna puhul suurendavad haavatavust infrastruktuuri olukorra halvenemine ja mitterahulik isiklik ruum kodus. 


\section{Kokkuvõte ja arutelu}

Käesoleva uuringu tulemused näitavad, et laste haavatavust suurendavad valdavalt vähene autonoomne otsustusvõime (õigus langetada eakohaseid otsuseid oma aja, ruumi, suhete ja tegevuse üle perekonnas, kodus, koolis), veebisuhtluse varjuküljed, massimeedia vahendusel sisendatud ohutunne. Laste ütlustes jäi kõige olulisema haavatavust vähendava aspektina kõlama lapse "mina" ning selle arengut väärtustavad inimsuhted ja keskkond. Intervjuudes tuli esile laste ja nende isade suhteid puudutav teema - kas isast lahuselamine või nõrk psühholoogiline kontakt isaga jms, mis viitab võimalikule laiemale isa (või ka mehe) rolli probleemsusele ühiskonnas. Materiaalsed väärtused on haavatavust vähendava tegurina lastele küll olulised, kuid ei domineeri võrreldes turvalise kodu, heade inimsuhete ja eneseteostusvõimalustega (sport ja muud huvialad). Muret tekitavatena tõid lapsed välja palju kohustusi (seoses kooliga, ka palju huviringe), veebiturvalisuse, globaalsed keskkonnaprobleemid ning rahvusvahelised konfliktid, hierarhilised suhted õpetajatega, meedia poolt vahendatud negatiivsed sõnumid.

Urie Bronfenbrenneri (1994) ökoloogilis-süsteemse arengumudeli järgi on lapse elusfäärid väga mitmeplaanilised, hõlmates nii isikutevahelist, ruumilist, institutsionaalset interaktsiooni kui ka kronoloogilist dimensiooni ning kõik need leidsid intervjuudes laste ütluste kaudu ka kajastust. Uurimuse tulemused lähevad suures osas kokku Tobia Fattore, Jan Masoni ja Elizabeth Watsoni (2007) varasemate tulemustega. Ka Eesti laste puhul sai kinnitust turvaliste ja heade inimsuhete olulisus haavatavuse minimeerijana, vajadus turvalise ja lastesõbraliku füüsilise keskkonna järele. Küll aga pole käesoleva uurimuse põhjal võimalik teha üldistusi, kui head-usalduslikud suhted on Eesti lastel oma perekonna, sõprade ja teiste oluliste isikutega. Käesolevas uurimuses saab välja tuua faktorid, mida lapsed peavad üldiselt oluliseks haavatavust vähendavate ja heaolu suurendavate aspektidena. Laste õnnelikkuse uuringu arvandmeliste ning intervjuuandmete kombineeritud käsitluse alusel oleks võimalik seda teemat täielikumalt avada.

Kui Fattore tõi koos kaasautoritega (2007) välja, et lastele on sageli olulised emotsionaalse, mitte majandusliku väärtusega esemed, siis Eesti lapsed sümboolse väärtusega esemeid ei maininud, küll aga teadvustasid majanduslike ressursside heaolu suurendavat iseloomu, kuid leidsid paljuski, et raha ja materiaalseid ressursse ei pruugiks ühiskonnas üle tähtsustada. See, kui lapsed majanduslikest raskustest otsesõnu ei räägi, võib mõningatel juhtudel viidata ka antud teemaga seostuvale abitusele ja häbitundele. Käesolevas uurimuses otsese materiaalse puuduse teema laste poolt käsitlemist ei leidnud. Erinevalt 
Fattore, Masoni ja Watsoni (2007) uurimusest ei ilmnenud käesolevas uurimuses, et Eesti lastel oleks religioon muude emotsionaalsete väärtuste kontekstis oluline haavatavust vähendav faktor.

Laste elus on veebi sotsiaalvõrgustikud olulisel kohal. Veebisuhtlus pakub mitmekesiseid suhtlusvõimalusi ning on laste jaoks atraktiivne. Lapsed tajuvad, et veebis peituvad ka teatud ohud (privaatsus, anonüümsus, mitte-eakohane materjal jms), kuid intervjuudes osalenud lapsed kinnitasid, et veebisuhtlusega seotud probleemid on olnud lahendatavad. Veebikeskkond tekitab lastes kohati ebaturvalisust, aga pakub ka häid võimalusi oma sotsiaalsust arendada, on oluline vahend autonoomsuse ja oma "mina" arendamisel sõpradega suhtlemisel.

Asjadest, mida õpilased muuta sooviksid ja "millest tavaliselt ühe inimese jõud üle ei käi”, tõid õpilased esile sotsiaalseid probleeme (majanduslik ebavõrdsus, asotsiaalsus). Selliste muutmist vajavate asjade hulgas nimetati ka ulatuslikke keskkonnaprobleeme (reostus, kliimamuutused). Esile toodi globaalse turvalisusega seotut, nagu sõjad, terrorism, rahu puudumine maailmas, aga ka meedias vahendatud negatiivseid käsitlusviise ja teemasid (nt põhjendamatute negatiivsete uudiste esitamine olulise info raamistikus; uuriva ajakirjanduse kohatine agressiivne iseloom). Laste arvates muutmist vajavate suurte teemade puhul on näha, et nende teemade tutvustamisel ja teadvustamisel on oluline roll meedial. Kui lapsed tajuvad neid üksikisiku poolt lahendamatute probleemidena, siis võib sellise info mõjul tekkida abitus: need olukorrad ja sündmused on nende silmis kuskil küllaltki lähedal, ent lapsel puudub võim ja kontroll nende üle. Võrreldes nooremate vanuserühmadega võib 6. klassi õpilaste haavatavus (eluga rahulolu vähenemise kaudu) olla seotud arengupsühholoogiliste iseärasustega. Peaaegu kõik lapsed ütlesid intervjuudes, et nad jälgivad päevauudiseid ühel või teisel moel. See võib viidata, et nende maailmakäsitlus on juba laiem kui noorematel vanuserühmadel ja nad tajuvad ulatuslikumalt n-ö suurt maailma või täiskasvanute maailma.

Kokkuvõttes ei saa tehtud uuringu andmete põhjal välja tuua ühte suurimat ja kaalukamat haavatavust põhjustavat või suurendavat aspekti Eesti laste elus, kuid valdavalt leidis kinnitust varasemates uuringutes ilmnenu, et kõige suurema mõjuga on lapsele olulised lähedased isikud (Cobb 1976; Lee \& Yoo 2015). Turvaline kodu (Kutsar et al. 2018), harmoonilised inimsuhted ja sobivad eneseteostusvõimalused koos optimaalsete materiaalsete võimalustega kätkevad endas kõige olulisemat laste haavatavust vähendavat mõju.

\section{Kommentaar}

1 Artikkel on seotud projektiga "Laste subjektiivne heaolu võrdlevas perspektiivis: metodoloogilised väljakutsed ja panus praktikasse" (PUT 1530). 


\section{Kirjandus}

Andresen, Sabine 2014. Childhood Vulnerability: Systematic, Structural, and Individual Dimensions. Child Indicators Research 7 (4), lk 699-713 (doi: 10.1007/s12187-014-9248-4).

Ben-Arieh, Asher 2006. Measuring and monitoring the well-being of young children around the world. Backround paper prepared for the Education for All Global Monitoring Report 2007. Strong foundations: early childhood care and education (http://unesdoc. unesco.org/images/0014/001474/147444e.pdf - 5. juuli 2019).

Braun, Virginia \& Clarke, Victoria 2006. Using thematic analysis in psychology. Qualitative Research in Psychology 3, lk 77-101 (doi: 10.1191/1478088706qp063oa).

Bronfenbrenner, Urie1994. Ecological models of human developement. International Encyclopedia of Education 3, 2. trükk. Oxford: Elsevier.

Bronfenbrenner, Urie \& Morris, Pamela A. (1998). The ecology of developmental processes. Damon, William \& Lerner, Richard M. (toim). Handbook of child psychology: Theoretical models of human development (1). New York: John Wiley, lk 993-1028.

Camfield, Laura \& Skevington, Suzanne M. 2008. On Subjective Well-Being and Quality of Life. Journal of Health Psychology 13, lk 764-775 (doi: 10.1177/1359105308093860).

Cobb, Sidney 1976. Social support as a moderator of life stress. Psychosomatic Medicine 38 (5), lk 300-314.

Corsaro, William A. 2015. The sociology of childhood. Los Angeles: Sage Publications.

Deatrick, Janet A. \& Faux, Sandra A. 1991. Conducting Qualitative Studies with Children and Adolescents. Morse, Janice M. (toim). Qualitative nursing research: A contemporary dialogue. Thousand Oaks, CA: SAGE Publications, lk 203-223 (doi: 10.4135/9781483349015).

Diener, Ed (2006). Guidelines for national indicators of subjective well-being and illbeing. Journal of Happiness Studies 7 (4), lk 397-404 (doi: 10.1007/s10902-006-9000-y).

Diener, Ed \& Suh, Eunkook 1997. Measuring Quality of Life: Economic, Social and Subjective Indicators. Social Indicators Research 40, lk 189-216.

Dinisman, Tamar \& Ben-Arieh, Asher 2015. The Characteristics of Children's Subjective Well-Being. Social Indicators Research 126 (2), lk 555-569 (doi: 10.1007/s11205-0150921-x).

Ezzy, Douglas 2002. Qualitative Analysis. Practice and Innovation. Crows Nest, NSW, Australia: Allen and Unwin.

Fattore, Tobia \& Mason, Jan \& Watson, Elizabeth 2007. Children's conceptualisation(s) of their well-being. Social Indicators Research 80 (1), lk 5-29.

Fattore, Tobia \& Fegter, Susann \& Hunner-Kreisel, Christine 2019. Children's Understandings of Well-Being in Global and Local Contexts: Theoretical and Methodological Considerations for a Multinational Qualitative Study. Child Indicators Research 12 (2), lk 385-407 (doi: 10.1007/s12187-018-9594-8). 
Given, Lisa M. (toim) 2008. The SAGE encyclopedia of qualitative research methods. Los Angeles: Sage Publications.

Goodin, Robert E. 1985. Protecting the Vulnerable: a re-analysis of our social responsibilities. Chicago: Chicago University Press.

Hill, Malcolm \& Laybourn, Ann \& Borland, Moira 1996. Engaging with primary-aged children about their emotions and well-being: Methodological considerations. Children \& Society 10, lk 129-144 (doi: 10.1111/j.1099-0860.1996.tb00463.x).

Hunner-Kreisel, Christine \& Kuhn, Melanie 2010. Children's perspectives: Methodological critiques and empirical studies. Andresen, Sabine \& Diehm, Isabel \& Sander, Uwe \& Ziegler, Holger (toim). Children and the good life: New challenges for research on children. Dordrecht: Springer, lk 115-118.

Krueger, Richard A. 1994. Focus Groups: A Practical Guide for Applied Research (2. trükk). Thousand Oaks: SAGE.

Kutsar, Dagmar \& Soo, Kadri \& Raid, Kadri 2018. Rahvusvaheline laste heaolu uuring võimalus arendada lastekeskset statistikat. Eesti Statistika kvartalikiri 1/18. Quarterly Bulletin of Statistics Estonia (e-väljaanne) (https://www.stat.ee/valjaanne-2018_eestistatistika-kvartalikiri-1-18 - 1. juuli 2019).

Lapse õiguste konventsioon = Lapse õiguste konventsioon. Riigi Teataja (https://www. riigiteataja.ee/akt/24016 - 4. juuli 2019).

Lee, Bong Joo \& Yoo, Min Sang 2015. Family, School, and Community Correlates of Children's Subjective Well-being: An International Comparative Study. Child Indicators Research 8, lk 151-175 (doi: 10.1007/s12187-014-9285-z).

Mason, Jan ja Hood, Suzanne 2011. Exploring issues of children as actors in social research. Children and Youth Services Review 33 (4), lk 490-495 (doi: 10.1016/j. childyouth.2010.05.011).

Minkkinen, Jaana 2013. The Structural Model of Child Well-being. Child Indicators Research 6 (3), lk 547-558 (doi: 10.1007/s12187-013-9178-6).

Moore, Tim 2015. Keeping them in mind. Schweiger, Gottfried \& Graf, Gunter (toim). The well-being of children: Philosophical and social scientific approaches. Warsaw \& Berlin: De Gruyter, lk 49-67 (doi: 10.1515/9783110450521).

Mullin, Amy 2014. Children, Vulnerability, and Emotional Harm. Mackenzie, Catriona \& Rogers, Wendy \& Dodds, Susan (toim). Vulnerability: New Essays in Ethics and Feminist Philosophy. Oxford: Oxford University Press, lk 266-286 (doi: 10.1093/acpro f:oso/9780199316649.003.0012).

Parker, Andrew \& Tritter, Jonathan 2006. Focus group method and methodology: current practice and recent debate. International Journal of Research and Method in Education 29 (1), lk 23-37 (doi: 10.1080/01406720500537304).

Punch, Samantha 2002. Research with Children: The Same or Different from Research with Adults? Childhood 9 (3), lk 321-341 (doi: 10.1177/0907568202009003005). 
Qvortrup, Jens 1991. Childhood as a Social Phenomenon - An Introduction to a Series of National Reports. Eurosocial Reports Series 36. Vienna: European Centre for Social Welfare Policy and Research.

Qvortrup, Jens 2009. The development of childhood: Change and continuity in generational relations. Qvortrup, Jens \& Brown Rosier, Katherine \& Kinney, David A. (toim). Structural, historical and comparative perspectives. Sociological studies of children and youth 12. Bingley: Emerald Group Publishing, lk 1-26.

Rees, Gwyther \& Lee, Jenny 2005. Still Running 2: Findings from the second national survey of young runaways. London: The Children's Society.

\title{
Summary
}

\section{Aspects of Estonian schoolchildren's vulnerability as based on 6th-graders' focus groups}

\author{
Andrus Tins \\ Postgraduate student \\ Institute of Social Studies, University of Tartu \\ andrus.tins@ut.ee
}

Keywords: children's vulnerability, insecurity, security, thematic analysis, wellbeing

In this paper the author examines the self-reported aspects of vulnerability of children in Estonia. The study is based on the data of four focus groups with 12-year-old children, conducted in Estonian schools in 2018-2019. The author gives an overview of the most important findings and compares those to a broader framework and understanding of vulnerability in childhood research. For example, the article describes the importance of secure relations between a child and the family or a child and other close persons. The article exemplifies that material resources are important to children but not more important than a secure home, good relations, and free-time activities. According to the opinions of the respondents, too many duties, poor online security, global environmental problems, international conflicts, hierarchical relations with teachers and negative messages of the mass media are the most worrying aspects. 